\title{
The Impact of Customer Concentration on the Tunneling of the Large Shareholders
}

\author{
Qinying Yuan \\ Jinan University, Guangzhou, China \\ Email: 18362905095@163.com
}

How to cite this paper: Yuan, Q. Y. (2020). The Impact of Customer Concentration on the Tunneling of the Large Shareholders. Modern Economy, 11, 368-382.

https://doi.org/10.4236/me.2020.112028

Received: January 16, 2020

Accepted: February 15, 2020

Published: February 18, 2020

Copyright $\odot 2020$ by author(s) and Scientific Research Publishing Inc. This work is licensed under the Creative Commons Attribution International License (CC BY 4.0).

http://creativecommons.org/licenses/by/4.0/

(c) (i) Open Access

\begin{abstract}
With the increasing concentration of the shareholding, the tunneling of the large shareholders has gradually become a hot topic in the field of corporate governance, which is a problem that is common in China's listed companies and needs to be solved urgently. This paper applies the supervisory role of stakeholders to corporate governance. Based on the research sample of non-financial listed companies in China from 2010 to 2017, we empirically examined the impact of customer concentration on the tunneling of the large shareholders. The research results show that the higher the concentration of customers, the lower the possibility of large shareholders' tunneling; the cash holdings have an intermediary role in the relationship between customer concentration and the tunneling of large shareholders; compared with those with low market position. The negative correlation between customer concentration and the tunneling of large shareholders is more pronounced in companies with high market positions. The conclusions of this paper are not only conducive to further understanding the corporate governance role of stakeholders, but also help to improve the corporate governance and protect the interests of investors.
\end{abstract}

\section{Keywords}

Large Shareholder's Tunneling, Customer Concentration, The Governance Effect, The Mediating Effect

\section{Introduction}

In China's unique economic background, most of the listed companies have evolved from state-owned companies, and the state-owned stocks have always dominated. Although this situation has improved since the split share structure reform, the phenomenon of equity concentration is still relatively common. 
When the shareholding structure is concentrated, it is often easy to induce the opportunistic behavior of large shareholders. Therefore, the controlling shareholder is likely to hollow out for his own benefit. The tunneling of the large shareholders has seriously harmed the company's interests. How to reduce this behavior becomes a hot topic.

The current literature mainly explores the inhibitory effect on the tunneling of the large shareholders from the perspectives of equity balances, media supervision, independent directors and external audit. At the same time, corporate customers as stakeholders also have governance effects on the company.

There is a "bundling effect" between the big customers and the company. Once penalties are imposed for violations, it will be difficult for the company to guarantee the supply of goods and follow-up services, which will disrupt the production order of big customers, and even cause them to fail in serious cases. In addition, changing suppliers will incur high conversion costs (Kale \& Shahrur, 2007), so big customers have a strong incentive to monitor the company's operating management. On the one hand, in order to ensure its own production safety and maintain the stability of the supply chain system, big customers will actively intervene in supplier's business management, which is a governance effect; on the other hand, due to the consideration of maintaining big customers relationships, the company also has an incentive to work hard to maintain itself good image (Raman \& Shahrur, 2008). If the funds were unreasonably occupied by the major shareholders, it would result in insufficient funds to support normal business activities and thus disrupt the stable production of major customers. Therefore, this article attempts to explore the impact of customer concentration on the tunneling of the large shareholders from the perspective of the governance effect of the big customers of the stakeholder from the demand for supervision.

The tunneling of the large shareholders has always been a serious phenomenon in China. Existing literature mainly studies the constraints of the tunneling of the large shareholders from the aspects of equity balances, media supervision, independent directors, and external audit. However, as an emerging market country, imperfect market supervision system restricts the restrictions on the tunneling of the large shareholders. As one of the company's most important external stakeholders, customers can not only have important impacts on the company's strategies and management policies, but also have corporate governance effects. From the perspective of the company's important stakeholders-customers, this article considers that large customers also have a strong motivation to monitor the status of the company, and provides a new perspective that can be based on stakeholder consideration. What's more, this article emphasizes that the company should focus on customers, strengthen the management of the company's supply chain and while improving business performance, the company should further strengthen the establishment of mutually beneficial cooperation with customers. 


\section{Hypothetical Development}

\subsection{Influencing Factors of the Tunneling of the Large Shareholders}

From the perspective of the external governance mechanism, legal supervision can play a fundamental governance role (Porta \& Shleifer, 1999), reporting negative media news also can effectively alleviate the tunneling of the large shareholders, and the effect is more obvious when there is a relatively complete legal regulatory environment (Ye, Huang, \& Li, 2015). Besides, based on the study of the characteristics of the board structure of listed companies in the UK, research found that the larger the proportion of directors, the more effective their supervisory role and the less likely the tunneling of the large shareholders will occur (Boateng \& Huang, 2017).

\subsection{Governance Effects of Customer Concentration}

When the concentration of customers is high, the company can integrate information and resources in the supply chain, thereby reducing the uncertainty of product demand, at the same time it can also reduce product transaction costs and customer retention costs, and improve inventory management efficiency and asset use efficiency, which in turn improve company performance. For example, customer concentration was significantly positively correlated with net asset interest rate and return on net assets (Patatoukas, 2012). Higher customer concentration can significantly improve corporate accounting robustness (Hui, Klasa, \& Yeung, 2012). In order to send a good signal to customers, companies tend to maintain low financial leverage (Banerjee, Dasgupta, \& Kim, 2008) and maintain a good image through charitable donations (Brammer \& Millington, 2006). Customers play a role in the market such as banks and other financial intermediaries which will continue to conduct external inspections and supervision to companies (Itzkowitz, 2015). And when the agency problem of the company is serious, the client will improve the governance problem through the cross-shareholding of the board of directors (Chang, Chen, \& Khimich, 2015).

\subsection{Comment}

At present, the research on the antecedents of the tunneling of the large shareholders is mainly based on agency theory. Many existing studies focus on independent directors, media supervision and external audit. At the same time, in the impact of customer concentration on the company, most of the views believe that large customers help to integrate the supply chain system and play a positive external governance effect.

This article believes that, for the sake of ensuring their own production safety and maintaining the efficiency of the supply chain system, big customers have an incentive to supervise the company, reduce moral hazard, and improve the company's production and operation efficiency. Therefore, considering the combination of tunneling of the large shareholders and customer concentration, 
we explore the role of customer concentration on tunneling of the large shareholders and analyze the mechanism from the perspective of internal and external governance, thereby expanding the field of research in this field.

\section{Research Hypothesis}

\subsection{The Impact of Customer Concentration on the Tunneling of the Large Shareholders}

First, due to the close economic relationship between the customer and the company, the customer has a strong incentive to supervise the company. For instance, customers can obtain the private information of suppliers, and in order to prevent the loss of customers, the company has the motivation to pass the company's operating information to customers to reduce information asymmetry and enhance customer confidence in company (Schloetzer, 2012). Customers play a role in the market such as banks and other financial intermediaries and will continue to conduct external inspections and supervision of enterprises (Itzkowitz, 2015). Therefore, clients can monitor the opportunistic behavior of the large shareholders, alleviate agency problems (Li \& Yang, 2011), and exert the governance effects of stakeholders.

Secondly, because the company itself is dependent on the big customers, it has its own motivation to strive to maintain a good image. Such as in order to obtain customer resources, companies will use charitable donations to send good signals to customers (Brammer \& Millington, 2006). The tunneling of the large shareholders is an unreasonable occupation of the company's funds, which may cause the company to have insufficient funds for normal business activities, unable to guarantee supplies, and thus affect customers. Based on this economic relationship, customers have an incentive to monitor the tunneling of the large shareholders. In addition, the information advantage of customers also allows them to better understand the company's operating conditions and effectively supervise and restrict the large shareholder's opportunistic behavior, alleviating agency problems. Based on the above logic analysis, this article proposes hypotheses:

H1: The higher the concentration of customers, the lower the chance of large shareholders being hollowed out.

\subsection{The Intermediary Role of Cash Holdings}

One of the most important forms of the tunneling of the large shareholders is the direct occupation of company funds. But for a company with a high concentration of customers, it may itself require a high level of cash. Customers are not willing to trade with suppliers in financial crisis. Therefore, if a company wants to establish a good cooperative relationship with customers, it must first send a signal of its own financial status to the customer as a commitment to alleviate the customer's concern about risk (Maksimovic \& Titman, 1991). Cash holdings can be used as a risk management tool (Bates, Kahle, \& Stulz, 2009), which can 
provide a good guarantee for customers. Therefore, for companies with a high concentration of customers, under the condition of maintaining a high level of cash holdings, the opportunity for the tunneling of the large shareholders is reduced.

H2: The cash holding level plays an intermediary role in the relationship between customer concentration and the tunneling of the large shareholders.

\subsection{The Moderating Role of Market Position}

The impact of customer concentration on the tunneling of the large shareholders will vary depending on the market position of the company. Most industries have one or several recognized leading companies. A company with strong market power means that its products have lower substitution and higher brand effects, more reasonable resource allocation (Nickell, Nicolitsas, \& Dryden, 1996). Therefore, the motivation of such companies to maintain customer relationships is not strong, and the role of customer governance is weakened, which increases the possibility of the tunneling of the large shareholders. Based on the above logic analysis, this article proposes hypotheses:

H3a: Compared with companies with low market positions, the negative correlation between customer concentration and the tunneling of the large shareholders is less significant in companies with high market positions.

In a market economy, companies in different industries have a common goal, that is, strive to maintain and improve their competitiveness and competitive position in the industry, so that they can take the initiative in fierce competition and achieve the goal of maximizing corporate profits and corporate sustainable development. In a company with a high market position, the higher the concentration of customers indicates that the majority of the company's market position comes from the purchasing power of one or several major customers, then if it loses important customer relationships, it will inevitably cause huge cash flow fluctuations in the company. It even led to financial distress for the company. Therefore, in this case, companies are more dependent on customers. In order not to lose these big customers and maintain their market position, they will be more willing to obey the supervision of big customers.

H3b: Compared with the companies with low market position, the negative correlation between the concentration of customers and the tunneling of the large shareholders is more significant in the companies with high market position.

\section{Study Design and Sample Selection}

\subsection{Sample Selection and Data Sources}

This article selects Chinese non-financial A-share listed companies from 2010 to 2017 as the initial observation. To improve the effectiveness of the study, ST companies and companies with missing data in the database were eliminated, which left 8075 firm-year observations for 1228 unique firms. All continuous va- 
riables in the model are Winsor processed at the $1 \%$ level. The data related to financial indicators in this article are from the CSMAR database which is currently the largest and most accurate financial and economic database in China, including financial statement data, financial indicator analysis data and so on. Stata 12.0 is used for data analysis.

\subsection{Variable Definition and Model Design}

This paper uses the ratio of other receivables to total assets as a proxy variable for the tunneling of the large shareholders (Jiang, Lee, \& Yue, 2010) and sales of top five customers/ total sales which disclosed in the annual report of listed companies to measure customer concentration. Cash and cash equivalents/total assets are used to measure a company's cash holding level. According to Zhang Xinming, the standard for market position classification is: when the ratio of the company's annual sales to industry sales is greater than median, the virtual variable MP of this company's market position is defined as 1 , otherwise it is defined as 0 , that is, $\mathrm{MP}=1$ represents the company's high market position, $\mathrm{MP}=0$ means that the company's market position is low.

In addition, in this paper, when examining the impact of customer concentration on the tunneling of the large shareholders, we also control the asset-liability ratio (Lev), return on assets (Roa), company size (Size), independent directors of the board (Indep), and types of audit opinions (Auditor), Separate Power (Sep), Growth (Growth), Bank Debt Ratio (Debt), Property right (SOE), Industry Dummy Variable (Industry), Annual Dummy Variable (Year).

\subsection{Model Design}

In order to test $\mathrm{H} 1$, the regression Equation (1) is constructed:

$$
\mathrm{Tu}=\alpha+\beta_{1} * \text { CC_top } 5+\beta_{2} * \text { Control }+\Sigma \text { Industry }+\Sigma \text { Year }+\varepsilon
$$

In Hypothesis 1, the main focus is on the coefficient of CC_top5. If the coefficient $\beta_{1}$ is significantly negative, it means that the higher the concentration of customers, the lower the possibility of the tunneling of the large shareholders, thereby verifying $\mathrm{H} 1$.

In order to test $\mathrm{H} 2$, the regression Equation (2) is constructed:

$$
\begin{gathered}
\mathrm{Tu}=\alpha+\beta_{1} * \text { CC_top } 5+\beta_{2} * \text { Control }+\Sigma \text { Industry }+\Sigma \text { Year }+\varepsilon \\
\text { Cash }=\alpha+\beta_{3} * \text { CC_top } 5+\beta_{4} * \text { Control }+\Sigma \text { Industry }+\Sigma \text { Year }+\varepsilon \\
\mathrm{Tu}= \\
\alpha+\beta_{5} * \text { CC_top } 5+\beta_{6} * \text { Cash }+\beta_{7} * \text { Control } \\
+\Sigma \text { Industry }+\Sigma \text { Year }+\varepsilon
\end{gathered}
$$

According to Wen Zhonglin, when the coefficient $\beta_{1}$ is significantly negative, the coefficient $\beta_{3}$ is significantly positive, and the coefficient $\beta_{6}$ is significantly negative, it shows that there is indeed an intermediary effect in the relationship between the concentration of customers and the tunneling of the large shareholders, Thereby verifying Hypothesis 2 . And if the coefficient $\beta_{5}$ is not significant, the cash holding amount is completely intermediary. 
In order to test $\mathrm{H} 3$, the regression Equation (3) is constructed:

$$
\begin{aligned}
\mathrm{Tu}= & \alpha+\beta_{1} * \mathrm{CC} \_ \text {top } 5+\beta_{2} * \mathrm{PCM}+\beta_{3} * \mathrm{CC} \_ \text {top5 } * \mathrm{PCM} \\
& +\beta_{4} * \text { Control }+\Sigma \text { Industry }+\Sigma \text { Year }+\varepsilon
\end{aligned}
$$

In H3, the CC_top5* PCM coefficient is mainly concerned. If the coefficient $\beta_{3}$ is significantly positive, it indicates that the negative correlation between the concentration of customers and the tunneling of the large shareholders is lower than that of companies in high market positions, hypothesis $3 \mathrm{a}$ is verified. If the coefficient $\beta_{3}$ is significantly negative, it indicates that the negative correlation between the concentration of customers and the tunneling of the large shareholders is more significant in the companies with higher market positions, thereby verifying hypothesis $3 \mathrm{~b}$.

\section{Empirical Test and Result Analysis}

\subsection{Descriptive Statistical Analysis}

Table 1 reports descriptive statistics of the variables in the entire sample. From Table $1, \mathrm{Tu}$ is used to measure the tunneling of the large shareholders. The average value is 0.0100 , the minimum value is 0.000 , and the maximum value is 0.1400 . CC_top5 is an indicator of the customer concentration of listed companies. Descriptive statistics show that the average value is 0.3000 , the maximum value is 0.9800 , the minimum is 0.0100 , and the standard deviation is 0.2100 , indicating that there is a large difference in customer concentration between different companies in China. Cash represents the amount of cash held by a company, with an average value of 0.1700 , a minimum value of 0.0100 , and a maximum value of 0.7000 , indicating that the level of cash held by different companies varies greatly. MP stands for market position, with an average value of 0.5100

Table 1. Descriptive statistics of the main variables of the entire sample.

\begin{tabular}{ccccccc}
\hline Variable & $\mathrm{N}$ & Mean & Sd & Min & P50 & Max \\
\hline Tu & 8075 & 0.0100 & 0.0200 & 0 & 0.0100 & 0.1400 \\
CC_top5 & 8075 & 0.3000 & 0.2100 & 0.0100 & 0.2400 & 0.9800 \\
Cash & 8075 & 0.1700 & 0.1300 & 0.0100 & 0.1300 & 0.7000 \\
MP & 8075 & 0.5700 & 0.5000 & 0 & 1 & 1 \\
Size & 8075 & 21.97 & 1.08 & 19.64 & 21.82 & 25.72 \\
Lev & 8075 & 0.4100 & 0.2000 & 0.0400 & 0.4000 & 0.9000 \\
Roa & 8075 & 0.0500 & 0.0400 & 0 & 0.0400 & 0.2300 \\
Sep & 8075 & 6.9600 & 8.3000 & 0 & 3.220 & 29.91 \\
Indep & 8075 & 0.3700 & 0.0500 & 0.1800 & 0.3300 & 0.7100 \\
Auditor & 8075 & 0.9800 & 0.1200 & 0 & 1 & 1 \\
Growth & 8075 & 0.2500 & 0.5800 & -0.6000 & 0.1300 & 4.5200 \\
Debt & 8075 & 0.3000 & 0.2300 & 0 & 0.3000 & 0.8200 \\
SOE & 8075 & 0.2200 & 0.4200 & 0 & 0 & 1 \\
\hline
\end{tabular}


In addition, the average value of whether a listed company was issued a standard unqualified opinion is 0.9800 , indicating that a large proportion of listed companies in China have been issued a standard unqualified opinion. The average SOE of property rights is 0.2200 . The minimum value of the asset-liability ratio Lev is 0.0400 and the maximum value is 0.9000 , indicating that the level of financial leverage used by listed companies in China is very different. The results of the company's size, ROA, the ratio of independent directors to the board, the growth of company, and the ratio of bank debt are basically the same as those of previous studies.

\subsection{Analysis of Regression Results}

In order to explore the impact of customer concentration on the culling of major shareholders, this paper performs a regression test on the model (1). The regression results are shown in Table 2.

As can be seen from Table 2, based on the regression analysis of customer concentration and the tunneling of the large shareholders, the coefficient of CC_top5 in the regression result is -0.0029 , which is significant at the level of $5 \%$. This shows that the higher the concentration of customers, the stronger the governance effect and therefore the less likely it is for the tunneling of the large shareholders.

Among the control variables, the coefficient of Lev is significantly positive, which indicates that the higher the corporate debt ratio, the worse the financial status of the enterprise may be, and the more likely the tunneling of the large shareholders. The coefficient of SIZE is significantly negative, indicating that the smaller the size of the company, the less perfect the internal supervision system, and the greater the opportunity for large shareholders to hollow out. The coefficient of auditor is significantly negative, indicating that when a non-unqualified opinion is issued, it indicates that the company is more likely to be hollowed out by the major shareholders. The coefficient of debt is significantly negative, indicating that the higher the corporate bank debt ratio, the less likely the tunneling of the large shareholders. The coefficient of SOE is significantly negative, which indicates that compared with non-state-owned companies, the system is transparent and the management is strict in state-owned enterprises, thus reducing the possibility of the tunneling of the large shareholders.

As can be seen from Table 3, the first column is the regression results of Model 2.1. The coefficient of CC_top5 is 0.0350 , which is significant at the $1 \%$ level. It shows that the higher the concentration of customers, the higher the level of cash held by companies. The second column is the regression result of Model 2.2. We can find that when the customer concentration and the company's cash holding level are put into the model at the same time, the coefficient of CC_top5 is -0.0027 , which is significant at the $5 \%$ level, and the coefficient of Cash is -0.0074 , significant at the $1 \%$ level. Combined with the three columns, it shows that the level of corporate cash holdings is indeed one of the paths that customer concentration affects the tunneling of the large shareholders. When 
Table 2. The results of customer concentration on the tunneling of the large shareholders.

\begin{tabular}{|c|c|}
\hline & $\mathrm{Tu}$ \\
\hline \multirow[t]{2}{*}{ CC_top5 } & $-0.0029^{* *}$ \\
\hline & $(-2.56)$ \\
\hline \multirow[t]{2}{*}{ Lev } & $0.0265^{\star * *}$ \\
\hline & (16.73) \\
\hline \multirow[t]{2}{*}{ Size } & $-0.0030^{\star * *}$ \\
\hline & $(-10.74)$ \\
\hline \multirow[t]{2}{*}{ Roa } & -0.0063 \\
\hline & $(-1.09)$ \\
\hline \multirow[t]{2}{*}{ Sep } & 0.0000 \\
\hline & $(1.46)$ \\
\hline \multirow[t]{2}{*}{ Indep } & 0.0025 \\
\hline & $(0.59)$ \\
\hline \multirow[t]{2}{*}{ Auditor } & $-0.0169^{* * *}$ \\
\hline & $(-9.32)$ \\
\hline \multirow[t]{2}{*}{ Growth } & 0.0004 \\
\hline & (1.11) \\
\hline \multirow[t]{2}{*}{ Debt } & $-0.0058^{\star * *}$ \\
\hline & $(-5.13)$ \\
\hline \multirow[t]{2}{*}{ SOE } & $-0.0013^{\star *}$ \\
\hline & $(-2.10)$ \\
\hline \multirow[t]{2}{*}{ _cons } & $0.0881^{* * *}$ \\
\hline & $(13.90)$ \\
\hline Industry & controlled \\
\hline Year & controlled \\
\hline $\mathrm{N}$ & 8075 \\
\hline $\mathrm{R}^{2}$ & 0.1762 \\
\hline Adjust- $\mathrm{R}^{2}$ & 0.1728 \\
\hline F value & 52.12 \\
\hline
\end{tabular}

***, **, ${ }^{*}$ represent significant levels at $1 \%, 5 \%$, and $10 \%$ respectively; $t$ values are reported in parentheses.

Table 3. The intermediary effect of cash holdings.

\begin{tabular}{cccc}
\hline & $(1)$ & $(2)$ & $(3)$ \\
& Cash & $\mathrm{Tu}$ & $\mathrm{Tu}$ \\
\hline CC_top5 & $0.0350^{* * *}$ & $-0.0027^{* *}$ & $-0.0029^{* *}$ \\
& $(5.50)$ & $(-2.33)$ & $(-2.56)$ \\
Cash & - & $-0.0074^{* * *}$ & - \\
& - & $(-3.67)$ & - \\
\hline
\end{tabular}




\section{Continued}

\begin{tabular}{|c|c|c|c|}
\hline \multirow[t]{2}{*}{ Lev } & $-0.2500^{* * *}$ & $0.0247^{\star * *}$ & $0.0265^{* * *}$ \\
\hline & $(-28.44)$ & (14.85) & $(16.73)$ \\
\hline \multirow[t]{2}{*}{ Size } & $0.0068^{\star * *}$ & $-0.0030^{* * *}$ & $-0.0030^{\star * *}$ \\
\hline & $(4.41)$ & $(-10.56)$ & $(-10.74)$ \\
\hline \multirow[t]{2}{*}{ Roa } & $0.2780^{\star * *}$ & -0.0043 & -0.0063 \\
\hline & $(8.62)$ & $(-0.74)$ & $(-1.09)$ \\
\hline \multirow[t]{2}{*}{ Sep } & -0.0002 & 0.0000 & 0.0000 \\
\hline & $(-1.17)$ & $(1.42)$ & (1.46) \\
\hline \multirow[t]{2}{*}{ Indep } & 0.0136 & 0.0026 & 0.0025 \\
\hline & $(0.58)$ & $(0.61)$ & $(0.59)$ \\
\hline \multirow[t]{2}{*}{ Auditor } & $-0.0191^{*}$ & $-0.0170^{* * *}$ & $-0.0169^{* * *}$ \\
\hline & $(-1.90)$ & $(-9.40)$ & $(-9.32)$ \\
\hline \multirow[t]{2}{*}{ Growth } & -0.0007 & 0.0004 & 0.0004 \\
\hline & $(-0.31)$ & (1.10) & $(1.11)$ \\
\hline \multirow[t]{2}{*}{ Debt } & $-0.1170^{\star \star \star}$ & $-0.0066^{* * *}$ & $-0.0058^{* * *}$ \\
\hline & $(-18.75)$ & $(-5.77)$ & $(-5.13)$ \\
\hline \multirow[t]{2}{*}{ SOE } & $0.0063^{\star}$ & $-0.0012^{\star *}$ & $-0.0013^{* *}$ \\
\hline & (1.91) & $(-2.03)$ & $(-2.10)$ \\
\hline \multirow[t]{2}{*}{ _cons } & $0.2110^{\star * *}$ & $0.0897^{\star * *}$ & $0.0881^{* * *}$ \\
\hline & (5.99) & (14.12) & (13.90) \\
\hline Industry & controlled & controlled & controlled \\
\hline Year & controlled & controlled & controlled \\
\hline $\mathrm{N}$ & 8075 & 8075 & 8075 \\
\hline $\mathrm{R}^{2}$ & 0.3523 & 0.1776 & 0.1762 \\
\hline Adjust- $\mathrm{R}^{2}$ & 0.3496 & 0.1741 & 0.1728 \\
\hline F value & 132.53 & 51.06 & 52.12 \\
\hline
\end{tabular}

${ }^{* * *}, * *,{ }^{*}$ represent significant levels at $1 \%, 5 \%$, and $10 \%$ respectively; $t$ values are reported in parentheses.

customer concentration is higher, companies tend to hold more cash based on preventive motivation and commitment motivation. On the other hand, directly occupying funds is the main form of the tunneling of the large shareholders, but when the company has high requirements for cash holding levels, it will reduce the opportunity for the tunneling of the large shareholders. Therefore, the cash holding level does have some intermediary effects.

In the first column, from the perspective of the regression of customer concentration on cash holdings, the coefficient of Lev is significantly negative in terms of control variables, indicating that the higher the corporate debt level, the lower the cash holdings level. The coefficient of Size is significantly positive, indicating that the larger the scale of the company, the higher the level of cash 
holdings. The coefficient of Roa is significantly positive, indicating that there is a positive correlation between the profitability of the company and the company's cash holdings. In the second column, in terms of control variables, the empirical results are basically consistent with the regression results of the model (4.1).

In order to explore the regulating role of the market position of companies, the regression test of model (3) is performed in this paper. The regression results are shown in columns (1), (2), and (3) of Table 4.

Table 4. The moderating role of market position.

\begin{tabular}{|c|c|c|c|}
\hline & $\begin{array}{c}(1) \\
\mathrm{Tu}(\mathrm{MP}=0)\end{array}$ & $\begin{array}{c}(2) \\
\mathrm{Tu}(\mathrm{MP}=1)\end{array}$ & $\begin{array}{c}(3) \\
\text { Total sample }\end{array}$ \\
\hline \multirow[t]{2}{*}{ CC_top5 } & 0.0004 & $-0.0056^{\star * *}$ & -0.0001 \\
\hline & $(0.24)$ & $(-3.73)$ & $(-0.09)$ \\
\hline \multirow[t]{2}{*}{ MP } & - & - & 0.0006 \\
\hline & - & - & $(0.69)$ \\
\hline \multirow[t]{2}{*}{$\mathrm{MP}^{\star}$ CC_top5 } & - & - & $-0.0055^{\star \star}$ \\
\hline & - & - & $(-2.56)$ \\
\hline \multirow[t]{2}{*}{ Lev } & $0.0317^{\star * *}$ & $0.0214^{* * *}$ & $0.0271^{\star * *}$ \\
\hline & $(13.01)$ & $(9.72)$ & $(16.70)$ \\
\hline \multirow[t]{2}{*}{ Size } & $-0.0048^{\star * *}$ & $-0.0018^{\star * \star}$ & $-0.0027^{\star * *}$ \\
\hline & $(-7.26)$ & $(-4.96)$ & $(-8.50)$ \\
\hline \multirow[t]{2}{*}{ Roa } & -0.0025 & $-0.0122^{*}$ & -0.0049 \\
\hline & $(-0.25)$ & $(-1.66)$ & $(-0.83)$ \\
\hline \multirow[t]{2}{*}{ Sep } & 0.0000 & $0.0001^{\star *}$ & 0.0000 \\
\hline & $(0.09)$ & $(2.16)$ & $(1.50)$ \\
\hline \multirow[t]{2}{*}{ Indep } & 0.0046 & -0.0031 & 0.0024 \\
\hline & $(0.65)$ & $(-0.60)$ & $(0.56)$ \\
\hline \multirow[t]{2}{*}{ Auditor } & $-0.0161^{\star * *}$ & $-0.0150^{\star \star *}$ & $-0.0165^{\star * *}$ \\
\hline & $(-6.85)$ & $(-4.83)$ & $(-9.10)$ \\
\hline \multirow[t]{2}{*}{ Growth } & -0.0008 & $0.0016^{\star * *}$ & 0.0004 \\
\hline & $(-1.23)$ & $(3.43)$ & $(1.04)$ \\
\hline \multirow[t]{2}{*}{ Debt } & $-0.0050^{* * *}$ & $-0.0055^{\star \star \star}$ & $-0.0058^{\star * *}$ \\
\hline & $(-2.90)$ & $(-3.65)$ & $(-5.13)$ \\
\hline \multirow[t]{2}{*}{ SOE } & $-0.0042^{\star * *}$ & -0.0001 & $-0.0012^{\star \star}$ \\
\hline & $(-3.75)$ & $(-0.11)$ & $(-2.09)$ \\
\hline \multirow[t]{2}{*}{ _cons } & $0.1270^{* * *}$ & $0.0629^{* * *}$ & $0.0815^{\star * *}$ \\
\hline & $(8.74)$ & (7.29) & $(11.45)$ \\
\hline Industry & controlled & controlled & controlled \\
\hline Year & controlled & controlled & controlled \\
\hline $\mathrm{N}$ & 3495 & 4580 & 8075 \\
\hline $\mathrm{R}^{2}$ & 0.1938 & 0.1840 & 0.1772 \\
\hline Adjust- $\mathrm{R}^{2}$ & 0.1861 & 0.1780 & 0.1736 \\
\hline $\mathrm{F}$ value & 25.21 & 31.05 & 49.47 \\
\hline
\end{tabular}

${ }^{* *},{ }^{* *},{ }^{*}$ represent significant levels at $1 \%, 5 \%$, and $10 \%$ respectively; $t$ values are reported in parentheses. 
It can be seen from Table 4 that the first two columns are the results of group regression. In the sample of companies in a low market position, the coefficient of customer concentration CC_top5 is 0.0004 . Although it is positive, the T value is 0.24 , which is not significant. In the sample of companies with high market position, the coefficient of customer concentration CC_top5 is -0.0056 , and the $\mathrm{T}$ value is -3.73 , which is significant at the $1 \%$ level. And the coefficient difference test between groups was performed, and the corresponding $\mathrm{P}$ value was 0.0496 .

The last column of Table 4 includes the crossover term MP ${ }^{*}$ CC_top5 of customer concentration and market position. It can be seen from the regression results that the coefficient of the crossover term MP ${ }^{\star}$ CC_top5 is -0.0055 , and it is significantly negative at the level of $1 \%$, which indicates that the term MP of the market position has indeed significantly enhanced the negative correlation between the concentration of customers and the tunneling of the large shareholders. This may be due to the higher concentration of customers in companies with high market status, which may indicate that one or several major customers have contributed major market shares. If these customers are lost, the impact on the company's market position will be huge. It is also very likely to cause huge cash flow fluctuations in the company and even cause the company to fall into financial distress. Therefore, for these companies, the external governance effect of the big customers is stronger.

This can prove that Hypothesis $3 \mathrm{~b}$, that is, a company in a higher market position, has a stronger inhibitory effect of customer concentration on the tunneling of the large shareholders. In terms of control variables, the empirical results are basically consistent with the regression results of the model (4.1).

\subsection{Robustness Test}

From the perspective of stakeholders, customers, as an important part of corporate governance, affect the development of a company and play an important role in the company's business strategy, investment efficiency, cash holding, and other aspects. On the one hand, due to consideration of their own sources of supply and cost risks, customers with bargaining power will take the form of active negotiation and effective supervision to influence the tunneling of the large shareholders. On the other hand, customers tend to cooperate in depth with companies with good corporate governance, which means that the company's tunneling of the large shareholders may also have a certain impact on customer concentration. Therefore, endogenous problems inevitably arise.

In order to solve this kind of problem, this paper calculated the lagging customer concentration and used it as a tool variable to perform regression using the two-stage least squares method. The corresponding regression results are shown in Table 5. From the results in the table, the coefficient of CC_top5_1 which is the lagging period of the customer concentration is -0.0036 which is significant at the level of $1 \%$ indicates the higher the concentration of customers, the less likely it is for the tunneling of the large shareholders. In terms of control 
Table 5. Robustness test: the impact of customer concentration on large shareholder tunneling.

\begin{tabular}{|c|c|}
\hline & $\mathrm{Tu}$ \\
\hline \multirow[t]{2}{*}{ CC_top5_1 } & $-0.0036^{\star * *}$ \\
\hline & $(-3.19)$ \\
\hline \multirow[t]{2}{*}{ Lev } & $0.0264^{* * *}$ \\
\hline & (16.69) \\
\hline \multirow[t]{2}{*}{ Size } & $-0.0030^{* * *}$ \\
\hline & $(-10.79)$ \\
\hline \multirow[t]{2}{*}{ Roa } & -0.0067 \\
\hline & $(-1.15)$ \\
\hline \multirow[t]{2}{*}{ Sep } & 0.0000 \\
\hline & (1.43) \\
\hline \multirow[t]{2}{*}{ Indep } & 0.0026 \\
\hline & $(0.63)$ \\
\hline \multirow[t]{2}{*}{ Auditor } & $-0.0169^{* * *}$ \\
\hline & $(-9.33)$ \\
\hline \multirow[t]{2}{*}{ Growth } & 0.0005 \\
\hline & $(1.22)$ \\
\hline \multirow[t]{2}{*}{ Debt } & $-0.0057^{\star * *}$ \\
\hline & $(-5.08)$ \\
\hline \multirow[t]{2}{*}{ SOE } & $-0.0013^{\star *}$ \\
\hline & $(-2.11)$ \\
\hline \multirow[t]{2}{*}{ _cons } & $0.0885^{\star * *}$ \\
\hline & (13.98) \\
\hline Industry & controlled \\
\hline Year & controlled \\
\hline $\mathrm{N}$ & 8075 \\
\hline $\mathrm{R}^{2}$ & 0.1766 \\
\hline Adjust- $\mathrm{R}^{2}$ & 0.1732 \\
\hline F value & 52.25 \\
\hline
\end{tabular}

${ }^{* * *},{ }^{* *},{ }^{*}$ represent significant levels at $1 \%, 5 \%$, and $10 \%$ respectively; $t$ values are reported in parentheses.

variables, it is basically consistent with the foregoing results, which shows that the conclusion of our basic analysis is robust.

\section{Conclusion and Limitation}

This article believes that the tunneling of the large shareholders as an act of unreasonably occupying the company's funds will result in the company not having sufficient funds for normal business activities, unable to guarantee supplies, and 
even cause customers failing. In addition, the proprietary assets invested by large customers also lost their expected value and generated high conversion costs. Therefore, customers have an incentive to monitor the tunneling of the large shareholders. On the other hand, for the sake of maintaining large customer relationships, the company also has an incentive to strive to maintain its good image. Therefore, the higher the concentration of customers, the more effectively they can curb the actions of the tunneling of the large shareholders. In addition, this paper also introduces the company's cash holding level as an intermediary variable, verifying that it does indeed have a partial intermediary effect in the impact of customer concentration on the tunneling of the large shareholders. Finally, from the perspective of market position, when the concentration of customers is high, for those companies with high market position, these customers make a great contribution to their market position, so they will have more right to speak, that is, strengthen the role of external governance.

However, the research in this article still has certain limitations:

First, the forms of the tunneling of the large shareholder are diverse and relatively hidden. The tunneling of the large shareholders not only occupies the company's funds, but also in many forms, such as connected transactions, on-the-job consumption, and embezzling investment opportunities. However the existing studies only consider one aspect when measuring the tunneling of the large shareholders, which will lead to inaccurate variable measurement. Therefore, it is necessary to find a proxy variable that accurately measures the tunneling of the large shareholders by integrating multiple hollowing out methods.

Second, despite the fact that large customers as stakeholders do have a supervisory role in the company; it ignores the "oversight costs" of large customers participating in governance. Existing research shows that supervision cost is also a key factor affecting the governance effect of stakeholders. Therefore, how to measure the "supervision cost" and how to consider it comprehensively are also a good direction for future research.

\section{Conflicts of Interest}

The author declares no conflicts of interest regarding the publication of this paper.

\section{References}

Banerjee, S., Dasgupta, S., \& Kim, Y. (2008). Buyer-Supplier Relationships and the Stakeholder Theory of Capital Structure. The Journal of Finance, 63, 2507-2552. https://doi.org/10.1111/j.1540-6261.2008.01403.x

Bates, T. W., Kahle, K. M., \& Stulz, R. M. (2009). Why Do U.S. Firms Hold So Much More Cash than They Used to? The Journal of Finance, 64, 1985-2021. https://doi.org/10.1111/j.1540-6261.2009.01492.x

Boateng, A., \& Huang, W. (2017). Multiple Large Shareholders, Excess Leverage and Tunneling: Evidence from an Emerging Market. Corporate Governance, 25, 58-74. 
https://doi.org/10.1111/corg.12184

Brammer, S., \& Millington, A. (2006). Firm Size, Organizational Visibility and Corporate Philanthropy: An Empirical Analysis. Business Ethics: A European Review, 15, 6-18. https://doi.org/10.1111/j.1467-8608.2006.00424.x

Chang, H., Chen, J., Khimich, N. V., \& Wu, G. S. (2015). Implications of Customer-Supplier Relationships on Corporate Governance. Rochester, NY: Social Science Electronic Publishing. https://doi.org/10.2139/ssrn.2640674

Hui, K. W., Klasa, S., \& Yeung, P. E. (2012). Corporate Suppliers and Customers and Accounting Conservatism. 53, 115-135. https://doi.org/10.1016/j.jacceco.2011.11.007

Itzkowitz, J. (2015). Buyers as Stakeholders: How Relationships Affect Suppliers' Financial Constraints. Journal of Corporate Finance, 31, 54-66. https://doi.org/10.1016/j.jcorpfin.2014.12.010

Jiang, G., Lee, C. M. C., \& Yue, H. (2010). Tunneling through Intercorporate Loans: The China Experience. Journal of Financial Economics, 98, 1-20.

https://doi.org/10.1016/j.jfineco.2010.05.002

Kale, J. R., \& Shahrur, H. (2007). Corporate Capital Structure and the Characteristics of Suppliers and Customers. Journal of Financial Economics, 83, 321-365. https://doi.org/10.1016/j.jfineco.2005.12.007

Li, N., \& Yang, Z. (2011). Customer Relationship and Debt Contracting. Rochester, NY: Social Science Electronic Publishing. https://doi.org/10.2139/ssrn.1923793

Maksimovic, V., \& Titman, S. (1991). Financial Policy and Reputation for Product Quality. Review of Financial Studies, 4, 175-200. https://doi.org/10.1093/rfs/4.1.175

Nickell, S., Nicolitsas, D., \& Dryden, N. (1996). What Makes Firms Perform Well? CEP Discussion Papers, 41, 783-796. https://doi.org/10.1016/S0014-2921(97)00037-8

Patatoukas, P. N. (2012). Customer-Base Concentration: Implications for Firm Performance and Capital Markets. Accounting Review, 87, 363-392. https://doi.org/10.2308/accr-10198

Porta, R., \& Shleifer, A. (1999). Corporate Ownership around the World. The Journal of Finance, 54, 471-517. https://doi.org/10.1111/0022-1082.00115

Raman, K., \& Shahrur, H. K. (2008). Relationship-Specific Investments and Earnings Management: Evidence on Corporate Suppliers and Customers. The Accounting Review, 83, 1041-1081. https://doi.org/10.2308/accr.2008.83.4.1041

Schloetzer, J. D. (2012). Process Integration and Information Sharing in Supply Chains. The Accounting Review, 287, 1005-1023. https://doi.org/10.2308/accr-10216

Ye, Y., Huang, L., \& Li, M. (2015). Negative Media Coverage, Law Environment and Tunneling of Controlling Shareholder. China Finance Review International, 5, 3-18. https://doi.org/10.1108/CFRI-12-2013-0135 